power of the notion of ability for this discourse of boundaries (as power and nonpower are doubled, recursive, inevitably a matter of the ability of ability), as well as for approaches to social or political categories. Disability scholars have begun explicitly to develop this line of thought in opening up the disability (or, more properly, dis/ability) involved in any expression of ability; indeed, disability studies has been moving in this direction for decades. A forthcoming special issue of Disability Studies Quarterly, titled Disability and Rhetoric (31.1 [2011]), promises to pursue this line, and Wolfe works with the ability-disability problematic in his recent book What Is Posthumanism? (U of Minnesota P, 2009). In short, the emergent emphasis on ability has great significance for the study of the human and of the products of humanity.

Scott DeShong

Quinebaug Valley Community College, CT

\section{The Radical-Teaching Debate}

\section{To THE EDITOR:}

Jacqueline E. Brady and Richard M. Ohmann rightly broadened the conversation in the Forum by justifying "teaching for social justice" (125.1 [2010]: 217-18). It takes wisdom like theirs to encapsulate years of theory into a case that views not informed by radical critique implicitly promote hegemonic values. Teachers who hold such views cannot lead useful debates.

Gerald Graff, whose 2008 Presidential Address prompted Brady and Ohmann's letter, needs to admit that in certain arenas "teaching the conflicts" stops making sense. Lawrence Summers lost his job as president of Harvard University in part because he still thinks the inherent scientific intelligence of women is debatable. In the academy, even if some scholars argue that slavery was an economically sound institution, we no longer debate its merit. Most well-informed people, like most scientists, think that the human impact on climate change would not make an interesting subject of debate. Would Graff approve of conducting a de- bate on the Bush torture memos? Much of what was "radical" in 1848, 1920, 1954, 1968, and 2004 is now mainstream. Teaching students to become radicals has simply led them to become early adopters of humane values that much of American society was blind to.

So what is left in 2010 to be shocked about in radicalism, or "critical thinking," and to cause Graff to complain that faculty members are influencing students politically in ways that "discredit" higher education? The main radical arguments today, I imagine, involve the failures of capitalism. Joseph Stiglitz and Paul Krugman, Jerome Groopman and Atul Gawande, David Cole and dozens of others now expound these in the mainstream: the failures of our health care system, our prison-industrial complex, and our overseas wars and the long-term high unemployment and midlife job discrimination that will affect almost all young people, even graduates of elite universities. It is the classrooms that never mention such issues, I submit, that are "isolated" and "self-protective" and deserve a responsible educator's scorn.

Margaret Morganroth Gullette Brandeis University

\section{Reply:}

Thanks to Margaret Morganroth Gullette for adding another historical dimension to the conversation that we have been having with Gerald Graff about radical teaching. Indeed, much of what was radical once is no longer so. It's hard to see why biologists today should back up 150 years and give creationism a fair shot in the classroom. Let them use their "power, experience, and control of academic discourse" (as Graff puts it in his reply to our letter) to teach evolutionary science. Graff's objection to our teaching critical and radical perspectives, even if "we are up-front about [our political] commitments and encourage our students to disagree with us," seems like an objection to college teaching in general, as commonly and quite properly done. Students take courses other than ours, few of them radical. Why not let students 